Contents list available at IJRED website

Int. Journal of Renewable Energy Development (IJRED)

Journal homepage: http://ejournal.undip.ac.id/index.php/ijred

\title{
Assessing The Current Indonesia's Electricity Market Arrangements and The Opportunities to Reform
}

\author{
Dhani Setyawan* \\ Centre for Climate Change Financing and Multilateral Policy, Fiscal Policy Office-Ministry of Finance of Indonesia, INDONESIA
}

\begin{abstract}
Existing subsidy arrangements and institutional settings in the Indonesian electricity sector distort investment decisions and lead to higher cost. Electricity supply is characterized by natural monopoly characteristics, requiring different management by governments than sectors with more straightforward market characteristics. Many countries have undergone significant re-structuring of their electricity sectors, away from one, state owned and vertically integrated monopoly supplier to a setting whereby competition has emerged either at the generation level and/or the retail level. Transmission and distribution networks are typically heavily regulated and transparent access arrangements are put in place as part of the restructuring efforts. The analysis showed that the current structure of Indonesia's electricity sector firmly within Model 2 (the single buyer model) and highlights that Indonesia is currently towards the less-competitive end of the spectrum of Model 2, identifying significant potential for efficiency enhancing reforms within this structure. Constitutional limitations have hampered previous efforts to restructure the sector in Indonesia but there is significant room for incremental reform to improve incentives in the sector and reduce the cost of generation in the process.
\end{abstract}

Keywords: analysis, electricity market, Indonesia, reform,

Article History: Received September 24, 2013; Received in revised form January 05, 2014; Accepted January 12, 2014; Available online

How to Cite This Article: Setyawan, D. (2014) Assessing The Current Indonesia's Electricity Market Arrangements and The Opportunities to Reform. Int. Journal of Renewable Energy Development, 3(1), 55-64.

http://dx.doi.org/10.14710/ijred.3.1.55-64

\section{Introduction}

Since the Asian Financial Crisis the growth in new electricity generation in Indonesia has struggled to keep up with demand. From 1997 to 2007 demand growth averaged 7 per cent per year (International Energy Agency 2008) but the increase in supply has been lagging behind. The slower than necessary pace of investment in new generation capacity means that by 2010 Indonesia had an estimated supply shortfall of 4.5 GW in 2010 (Jakarta Globe 2010) or an output shortfall of around 100 billion kwh per year. In 2009, it was estimated that energy output was some 170 billion KWh well short of the 260 - 290 billion kwh that would have needed to avoid rationing (Jakarta Globe 2010).

Compounding the challenge posed by the existing supply shortfall, growth in demand for electricity is forecast to average 9.5 per cent per year out to 2029 and beyond with likely higher rates outside the main Java-Bali grid (Ministry of Energy and Mineral Resources-MEMR 2012). In addition to building new supply capacity Indonesia will also have to replace aging infrastructure. Reuters has reported that PLN'S current generation capacity is around 25,000 MW although actual daily output is far less because most of its plants are old and inefficient. This suggests that there may need to be substantial new investment in supply just to maintain existing output let alone meet new demand.

To satisfy this level of demand Indonesia will have to build an additional $7.8 \mathrm{GW}$ of new capacity on average each year for the next 20 years. This is significantly more than the average of less than $1200 \mathrm{MW}$ that were added over the five years to 2009 . The capacity to

\footnotetext{
* Corresponding author:

E-mail: dhanisetyawan83@gmail.com
} 
Citation: Setyawan, D. (2014) Assessing The Current Indonesia's Electricity Market Arrangements and The Opportunities to Reform. Int. Journal of Renewable Energy Development, 3(1), 55-64 doi: 10.14710/ijred.3.1.55-64 $\mathrm{P}$ a g e $\mathbf{5 6}$

satisfy the projected increase in demand for electricity will be of critical importance to Indonesia as it fuels economic growth. Unmet demand and supply disruptions - which invariably result from less installed capacity than is required - undermine the attractiveness of Indonesia as an investment destination and harm its competitiveness. Supply expansion is also essential to satisfy the GOI's goal of increase electrification rates from around 66 percent in 2008 to 80 per cent by 2014 (National Medium Term Plan 2010 - 2014) and more than 90 per cent by 2020 (MEMR 2012).

The low electricity tariffs and the high subsidization of the PLN have become one of the biggest structural problems in the Indonesian electricity sector. Those conditions are responsible for developing an inefficient electricity market structure that is also unreceptive to both foreign and domestic investment. With artificially low electricity tariffs, and the government subsidizing the bulk of electricity production costs, most foreign investors and power operators that have the potential to alleviate some of the acute electricity shortages in Indonesia, have kept their distance (Purra 2010). With the existing tariff levels most power projects are financially unviable particularly for many of the multinational power companies.

Based on the aforementioned background, this study was conducted in order to analyze the Indonesian existing electricity market arrangements and the opportunities to glean lessons from International best practices of efficient arrangements in electricity sector. This study follows the following structure. In the beginning, this study elaborates the concept of natural monopoly. Further, the study provides a brief picture of Indonesia electricity sector arrangements and their history. Then, this paper goes through four different possible electricity industry structures that represent increasing penetration of competition in the Indonesia electricity sector.

This paper utilizes a descriptive methodology analysis. The secondary data are employed to support the analysis. In-depth interviews with some experts and focus group discussions are also part of the research methods employed in this study.

\section{Literature Review}

According to Sherer (1980), a natural monopoly can be found in an industry where a single business firm can produce total output to supply the market at a lower per unit-cost than can two or more firms (subadditivity of the cost functions). Another definition of natural monopoly was that of Baumol (1977), who argued that a natural monopoly exists when a single firm opeates in a market in which entrants are incapable of survival, even in the absence of predatory measures by the incumbent monopolist (sustainability of monopoly).
Utilities such as electricity, telecommunication, water and gas are often cited as examples of natural monopoly (Kim \& Horn 1999). These industries confront a relatively high fixed cost structures which the costs needed to produce even a small amount are high. Successively, once the initial investment has been made, the average costs decrease with every unit produced. Competition in these industries is deemed socially undesirable because the existence of a large number of firms would result in needless duplication of capital equipment (Depoorter 1999).

In the context of the electricity sector, the network component of the supply chain has the strongest natural monopoly characteristics. While generation facilities can feasibly be duplicated (or separated) and compete in a market with sufficient size, the economies of scale associated with building and operating a network are such that duplication is unlikely to ever be feasible. For example, Yarrow (1994) observes that the most European Union countries follow the model of a competitive or potentially competitive generation sector and a natural monopoly network sector. This observation implies a different approach to regulating the generation and network elements of the electricity sector. Under the correct market structure (e.g. diversified ownership) and regulatory regime competition in the generation sector can result in economically efficient outcomes and marketdetermined prices. Conversely, the natural monopoly network sector is likely to require extensive regulation or government involvement to ensure economically efficient outcomes.

This occurs because, as observed by Depoorter (1999), the natural monopoly concept poses a public policy dilemma. On the one hand, a natural monopoly implies that efficiency in production would be better served if a single firm supplies the entire market. On the other hand, in the absence of any competition the monopolist will be tempted to increase prices so as to maximize profits. It is also questionable whether a firm will pursue cost minimization under natural monopoly.

In the context of electricity networks, two broad responses to natural monopoly have been observed (Donald 1959). One response is to retain the network in government hands, using public pressure on the government to constrain the network's exercise of its monopoly power. The other is to privatise or corporatize the network (i.e. allow it to operate independently of government and pursue profitmaximisation) but subject it to extensive price and access regulation to ensure economically efficient outcomes.

The different treatments of generation and network elements are reflected in the different models of electricity market structure considered in subchapter below. The models discussed describe a broad evolution from non-competitive to competitive electricity markets, and illustrate how the potentially competitive 
generation sector is firstly opened to competition, with the retail sector following, whilst the non-competitive network components are regulated separately.

\section{Discussion and Analysis}

\section{a. Natural Monopoly in the Indonesian Electricity Sector}

The Indonesian electricity sector is characterised by heavily subsidized tariffs to end consumers (Pintz \& Korn 2005). Based on the latest Fiscal Policy Agency data of 2013 (Fig. 1.), it shows the trend of electricity subsidy in Indonesian state budget for the last 12 years. Although the electricity subsidy fluctuated between 2007 and 2013, overall the subsidy has shown an increasing trend. Subsidised tariffs effectively entrench a government monopoly in the supply of electricity to end users (electricity retailing) in Indonesia, as no private entity would compete to supply customers at a loss-making tariff. Consequently the state-owned company PT PLN exclusively retails electricity in Indonesia. The extent to which allowable tariffs are below generation costs. The trend of electricity's subsidy, are shown in the Table 1.

For a long time, retail electricity prices in Indonesia have been influenced by political considerations (World Bank 2005) and therefore future increases from subsidised to cost-reflective levels will likely occur gradually. Further, for political reasons, prices are regulated to be uniform across regions, creating a cross subsidy between Java (where economies of scale make generation costs relatively low) and other islands. The breakdown of PLN subsidies by user class in 2010 and 2011 are shown in Table 1.

Whilst tariffs differ between user classes, the pattern of tariffs are not cost-reflective and create distortions across consumer classes. A competitive electricity retail environment would require not only the general level of electricity tariffs to be cost-reflective, but also that tariffs for different user classes are also cost-reflective. Based on the data of PT. PLN (Fig. 2), it can be seen the proportions of electricity subsidy between different classes of customers per month, although it can not clearly define the cost-reflectiveness.

Some private participation has gradually emerged in Indonesia's electricity generation sector. Prior to 1985 , the power sector was entirely government-led, under the direction of the state-owned company PT PLN. In 1985 the Government issued Law No. 15/1985, allowing the participation of the private sector in electricity generation for its own use and to sell to PT PLN. The law sought to permit limited participation in electricity generation. Essentially, the law allowed for private parties (Independent Power Producers/IPPs) to supply electricity in Indonesia which was previously exclusive to PLN. These IPPs were licensed to sell their electricity solely to PLN pursuant to Power Purchase Agreements (PPAs). A power purchase agreement (PPA) is a contract for the sale of energy, availability and other generation services from an independent power producer (IPP). It is normally developed between the owners of private power plants and the buyer of the electricity. However, this IPP program was effectively frozen in the late 1990s when the financial crisis hit.

Electricity restructuring in Indonesia began in early 1992 when the Government opened the electricity generation market to competition. Following Presidential Decree No. 37 of 1992, which opened entry into generation markets, a number of permits have been issued for Independent Power Producers (IPP) to build, install and operate power plants, and sell the generated electricity to PT PLN for distribution to the public.

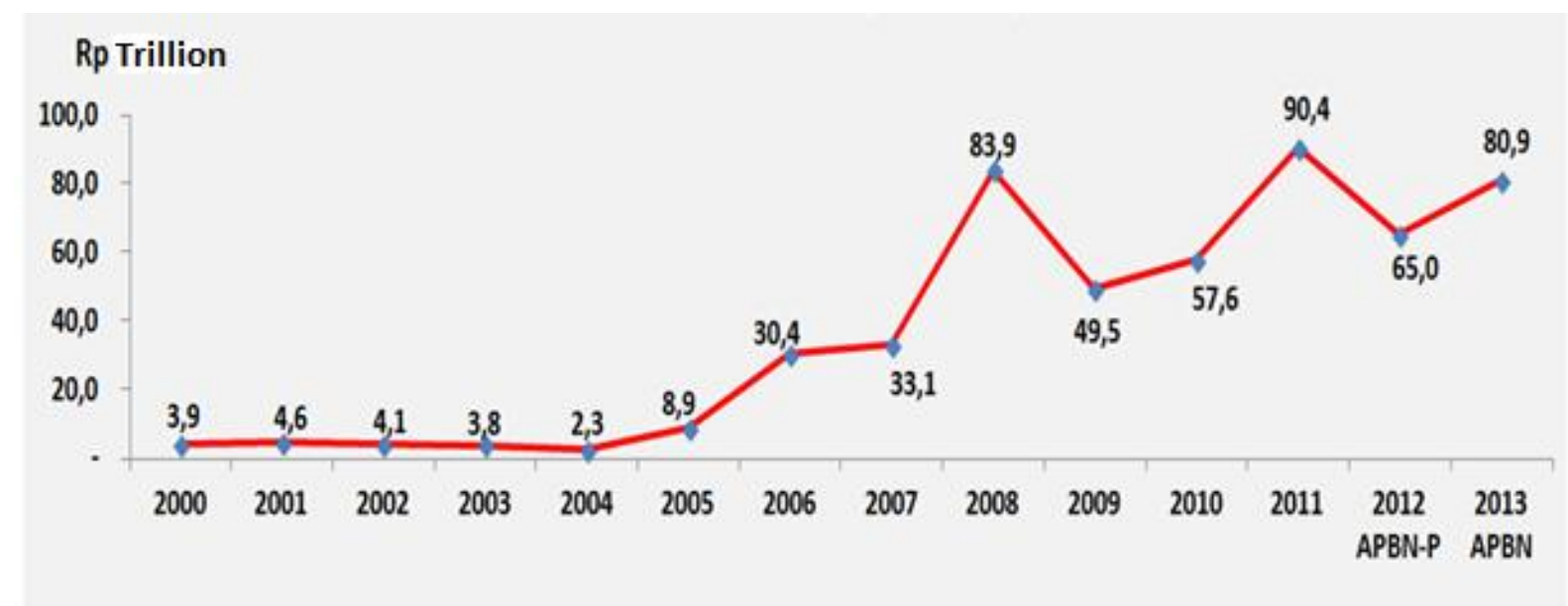

Source: Fiscal Policy Agency, 2013.

Fig 1. Trend of Electricity Subsidy 
Citation: Setyawan, D. (2014) Assessing The Current Indonesia's Electricity Market Arrangements and The Opportunities to Reform. Int. Journal of Renewable Energy Development, 3(1), 55-64 doi: 10.14710/ijred.3.1.55-64

$\mathrm{P}$ a g e $\mathbf{5 8}$

Table 1.

Average PLN Tariffs

\begin{tabular}{|c|c|c|c|c|}
\hline \multirow[b]{2}{*}{ Tariff Class } & \multicolumn{2}{|c|}{2010} & \multicolumn{2}{|c|}{2011} \\
\hline & $\begin{array}{c}\text { Revenue } \\
\text { (Million Rp) }\end{array}$ & $\begin{array}{c}\text { Subsidy } \\
\text { (Million Rp) }\end{array}$ & $\begin{array}{c}\text { Revenue } \\
\text { (Million Rp) }\end{array}$ & $\begin{array}{c}\text { Subsidy } \\
\text { (Million Rp) }\end{array}$ \\
\hline S.1 / $220 \mathrm{VA}$ & 153 & 1.559 & 116 & 1.273 \\
\hline S.2 / $450 \mathrm{VA}$ & 101.276 & 264.004 & 100.927 & 338.668 \\
\hline S.2 / $900 \mathrm{VA}$ & 159.799 & 254.320 & 167.806 & 360.433 \\
\hline $\mathrm{S} .2 / 1.300 \mathrm{VA}$ & 115.016 & 115.850 & 137.100 & 178.579 \\
\hline $\mathrm{S} .2 />2.200 \mathrm{VA}$ & 107.055 & 93.540 & 129.344 & 151.277 \\
\hline $\mathrm{S} .2 />2.200 \mathrm{~s} / \mathrm{d} 200 \mathrm{kVA}$ & 1.036 .124 & 685.812 & 1.226 .513 & 1.028 .658 \\
\hline $\mathrm{S} .3>200 \mathrm{kVA}$ & 720.686 & 408.426 & 915.249 & 586.211 \\
\hline Sub Total S & 2.240 .109 & 1.823 .511 & 2.677 .054 & 2.645 .099 \\
\hline R.1 / s/d 450 VA & 7.767 .008 & 14.003 .419 & 7.849 .024 & 19.045 .898 \\
\hline R.1 / 900 VA & 11.541 .896 & 10.917.259 & 12.505 .715 & 17.438 .553 \\
\hline R.1 / 1.300 VA & 6.460 .099 & 4.246 .264 & 8.601 .575 & 6.807 .422 \\
\hline R.1 / $2.200 \mathrm{VA}$ & 4.089 .127 & 2.626 .665 & 5.207 .934 & 4.000 .516 \\
\hline R. 2 / > $3.500 \mathrm{~s} / \mathrm{d} 5.500 \mathrm{VA}$ & 3.292 .967 & 1.412 .097 & 3.804 .794 & 2.157 .570 \\
\hline R. 3 / > 6.600 VA & 2.637 .533 & - & 2.859 .512 & 561.791 \\
\hline Sub Total R & 35.788 .630 & 33.205 .703 & 40.828 .554 & 50.011 .751 \\
\hline B.1 / s/d $450 \mathrm{VA}$ & 153.395 & 189.522 & 147.958 & 261.115 \\
\hline B.1 / $900 \mathrm{VA}$ & 366.184 & 323.945 & 363.910 & 483.374 \\
\hline B.1 / $1.300 \mathrm{VA}$ & 589.131 & 377.113 & 721.560 & 544.560 \\
\hline B.1 / $2.200 \mathrm{VA} \mathrm{s} / \mathrm{d} 5.500 \mathrm{VA}$ & 1.430 .397 & 662.313 & 2.593 .066 & 1.359 .655 \\
\hline B. 2 / $6.600 \mathrm{VA} \mathrm{s} / \mathrm{d} 200 \mathrm{kVA}$ & 11.347 .396 & 430.491 & 11.001 .767 & 2.214 .562 \\
\hline B. $3 />200 \mathrm{kVA}$ & 9.246 .775 & 1.740 .871 & 10.183 .912 & 4.244 .487 \\
\hline Sub Total B & 23.133 .278 & 3.724 .256 & 25.012 .172 & 9.107 .753 \\
\hline $\mathrm{I} .1 / 450 \mathrm{VA}$ & 81 & 115 & 82 & 167 \\
\hline I.1 / 900 VA & 469 & 462 & 470 & 656 \\
\hline $\mathrm{I} .1 / 1.300 \mathrm{VA}$ & 923 & 469 & 1.003 & 912 \\
\hline $\mathrm{I} .1 / 2.200 \mathrm{VA}$ & 2.953 & 984 & 2.568 & 1.916 \\
\hline $\mathrm{I} .1 / 3.500 \mathrm{~s} / \mathrm{d} 14 \mathrm{kVA}$ & 179.600 & - & 106.580 & 49.550 \\
\hline I. 2 / > $14 \mathrm{kVA} \mathrm{s} / \mathrm{d} 200 \mathrm{kVA}$ & 3.124 .578 & 1.319 .042 & 3.544 .726 & 2.058 .504 \\
\hline $\mathrm{I} .3 />200 \mathrm{kVA}$ & 23.110 .610 & 11.819 .140 & 27.254 .847 & 18.841 .779 \\
\hline $\mathrm{I} .4 />30.000 \mathrm{kVA}$ & 6.645 .263 & 4.339 .239 & 7.683.198 & 7.211 .048 \\
\hline Sub Total I & 33.064 .477 & 17.479 .452 & 38.593 .474 & 28.164 .534 \\
\hline P.1 / s/d 450 VA & 12.126 & 8.731 & 11.120 & 12.007 \\
\hline P.1 / 900 VA & 26.111 & 12.629 & 26.410 & 20.788 \\
\hline P.1 / 1.300 VA & 34.123 & 16.436 & 40.303 & 23.220 \\
\hline P.1 / $2.200 \mathrm{VA} \mathrm{s} / \mathrm{d} 5.500 \mathrm{VA}$ & 63.418 & 25.345 & 127.318 & 70.790 \\
\hline P.1 / 6.600 s/d $200 \mathrm{kVA}$ & 1.345 .355 & 3.903 & 1.361 .338 & 275.745 \\
\hline P. $2 />200 \mathrm{kVA}$ & 926.405 & 325.872 & 1.092 .452 & 540.386 \\
\hline P.3 & 2.156 .509 & 1.284 .316 & 2.500 .075 & 1.808 .696 \\
\hline Sub Total P & 4.564 .048 & 1.677 .232 & 5.159 .016 & 2.751 .632 \\
\hline $\mathrm{T} />200 \mathrm{kVA}$ & 55.871 & 33.257 & 57.208 & 52.375 \\
\hline $\mathrm{C} />200 \mathrm{kVA}$ & 83.086 & 72.880 & 53.434 & 55.677 \\
\hline $\mathrm{L}$ & 1.491 .097 & 92.126 & 1.688 .031 & 388.920 \\
\hline TOTAL & 100.420 .596 & 58.108 .418 & 114.068 .944 & 93.177 .740 \\
\hline
\end{tabular}

Indonesia's 2002 Electricity Law went further and envisaged competition and private participation in both electricity generation and retailing. However, in December 2004, Indonesia's Constitutional Court annuled the 2002 Electricity Law on the basis that it was in violation of the spirit of article 33 of the Indonesian Constitution. According to the Constitutional Court, electricity is a public good and its generation and distribution should remain under the exclusive control of the government.
In effect, the annullment of the 2002 Electricity Law reestablished the 1985 law and limited private participation in the sector to IPPs generating electricity and on-selling to PLN. Whilst IPPs participate in generation, this does not occur under competitive or even quasi-competitive conditions, but rather as an 'out-sourced' element of the PLN monopoly supply chain, meaning that electricity generation in Indonesia effectively operates within an essentially noncompetitive structure. 


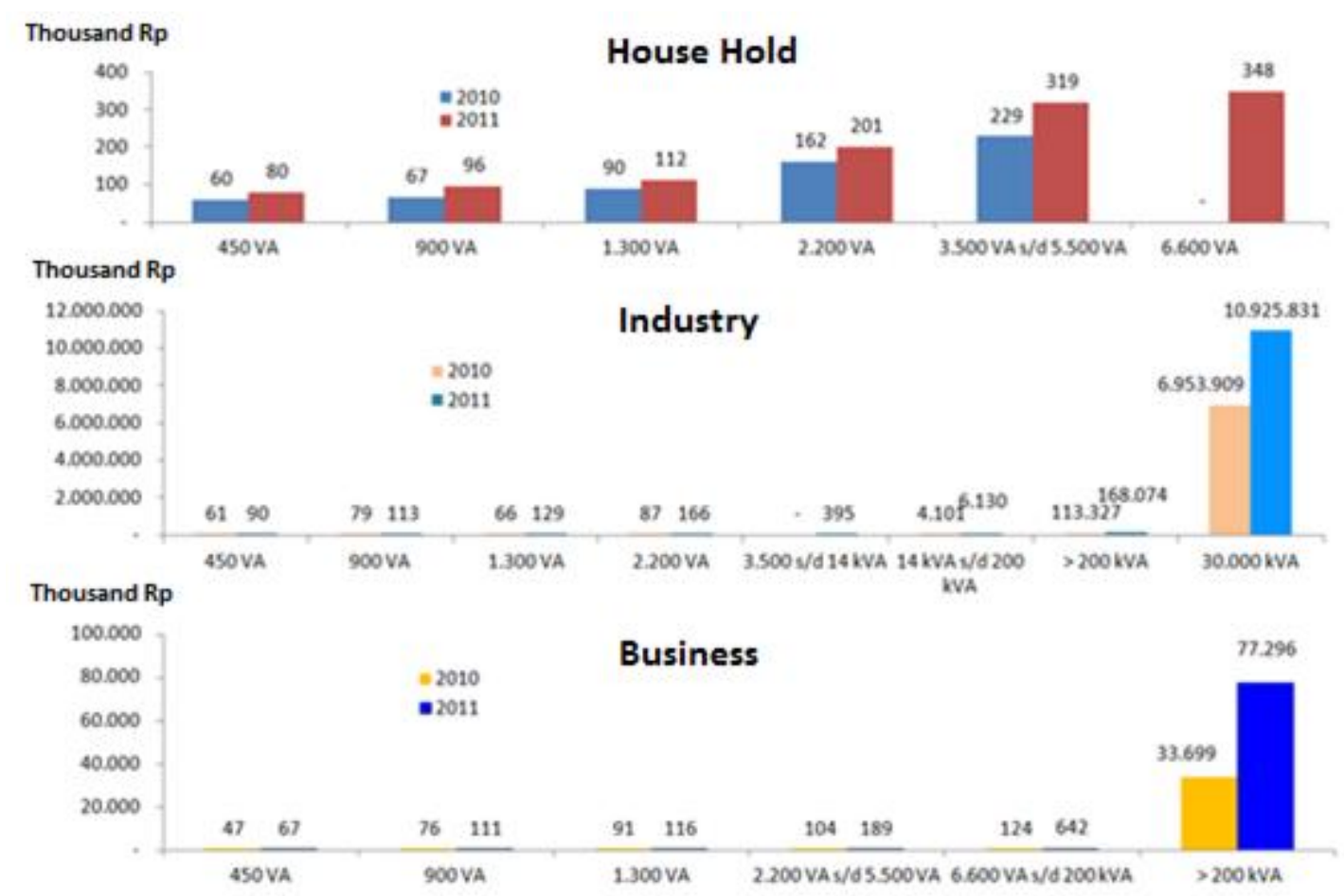

Source: PT PLN (Persero), 2012

Fig. 2 Electricity Subsidy per Customer per Month

Together, the low electricity tariffs and the high subsidies to PLN have resulted in an inefficient electricity market structure that is also unreceptive to both foreign and domestic investment. With artificially low electricity tariffs, and the government subsidizing the bulk of electricity production costs, most foreign investors and power operators that have the potential to alleviate some of the acute electricity shortages in Indonesia, have kept their distance (Purra 2010). With the existing tariff levels most power projects are financially unviable particularly for many of the multinational power companies.

In 2009, the government passed a new Electricity Law to strengthen the regulatory framework and provide a greater role for regional governments in terms of licensing and in determining electricity tariffs. The Law firmly justifies the state as the regulator of electricity supply and the PLN as the supplier, as stipulated in the article 33 of constitution (Articles 3 and 4 of the Electricity Law No. 30/2009). The substantial change is that the law authorizes the provincial governments to publish regulations on electricity. It also permits provinces to adjust electricity tariffs (Article 5 of the Electricity Law No. 30/2009). Whilst these are positive measures to improve the operation of the electricity sector, the monopoly position of PLN remains largely intact.

\section{b. Natural Monopoly in the Indonesian Electricity Sector}

There are four basic models for electricity industry structure that represent increasing penetration of competition in the sector:

1. Model 1: Vertically Integrated Monopoly

2. Model 2: Single Buyer Model

3. Model 3: Wholesale Competition

4. Model 4: Retail Competition

As discussed below, the present circumstances in Indonesia place it within the broad definition of Model 2 (the single buyer model). However, variation within this model exists and Indonesia is towards the lesscompetitive end of the spectrum of single buyer electricity market models.

\section{Model 1: Vertically Integrated Monopoly}

This model operates via a geographic monopoly on selling electric power to consumers, where all of the aspects of the electricity supply chain, i.e. generation, transmission, distribution and retailing, are conducted by a single utility within its region (Stănciulescu 2004; Andika \& Dewanda 2004). In this model, customers have no alternatives except to purchase electricity from their own local utility and so there is no competition at the retail level. Further, the utility generates and 
Citation: Setyawan, D. (2014) Assessing The Current Indonesia's Electricity Market Arrangements and The Opportunities to Reform. Int. Journal of Renewable Energy Development, 3(1), 55-64 doi: 10.14710/ijred.3.1.55-64 $\mathrm{P}$ a g e $\mid \mathbf{6 0}$

distributes all electricity itself, implying no competition between generation sources.

Typically electricity sectors take this form in countries that have not pursued market-oriented reforms. Given the evident market power the vertically integrated power company (VIPC) wields under this model, it is typically government-owned and voluntarily constrains prices for political reasons. Before the enactment of Electricity Law of 1985, Indonesia employed this model with PLN taking the role of the vertically integrated monopoly (as illustrated in Fig.3).

Such an arrangement usually results in implicit or explicit government subsidies to sustain the viability of the entity. In turn, this often creates poor incentives to minimise costs, which are therefore inefficiently high. This observation reflects the experience in Indonesia. In effect the Government of Indoenesia has ensured a certain price to protect customers by subsidizing the difference between the true cost and the regulated price. As this subsidy comes from state budget, the ongoing costs damage the GOI's financial position. Although Indonesia has moved from this model to a versoin of the 'single buyer model' discussed below since 1985, the essential difficulties of the vertically integrated model remain present in Indonesia's electricity sector today.

As an alternative to government-ownership and political constraints on electricity prices, some jurisdictions (notably a range of US states) employ what is called 'rate of return' regulation to set electricity prices charged by a VIPC. This regulation involves estimating in advance the reasonable costs associated with delivering all elements of the electricity supply chain and setting regulated tariffs that allow the operator to earn revenues to recoup these costs, plus a profit margin. The difficulty with this approach is that the VIPC generally perceives such regulation as guaranteeing a mark-up on costs, and it must share the benefits of measures to reduce costs with consumers through future tariff-setting processes. Consequently, the incentive for cost-minimisation is diluted and efficient outcomes are difficult to obtain.

\section{Model 2: Single buyer/purchasing agency model}

The single buyer/purchasing agency model represents a movement away from the vertically integrated model in the direction of greater competition, but the degree of increased competition varies depending on several specific design elements. Structurally, the key difference is that the VIPC (typically government-owned) diversifies its generation sources by contracting private investors (IPPs) to construct and operate generators. The IPPs sell their output to the VIPC, generally via long-term power purchase agreements (PPAs). Generally the VIPC will continue to operate its own generators in parallel with the IPPs but will be the sole purchasing agency for wholesale electricity. Meanwhile, the VIPC will coordinate dispatch of the various generation sources and maintain the transmission network.

The single buyer model (Fig. 4) certainly provides an emerging electricity sector with access to private capital and a diversity of generation companies. However, the extent to which it creates competitive pressure is highly dependent on detailed design elements. Designs representing two extremes of the spectrum of competitive outcomes can be identified.

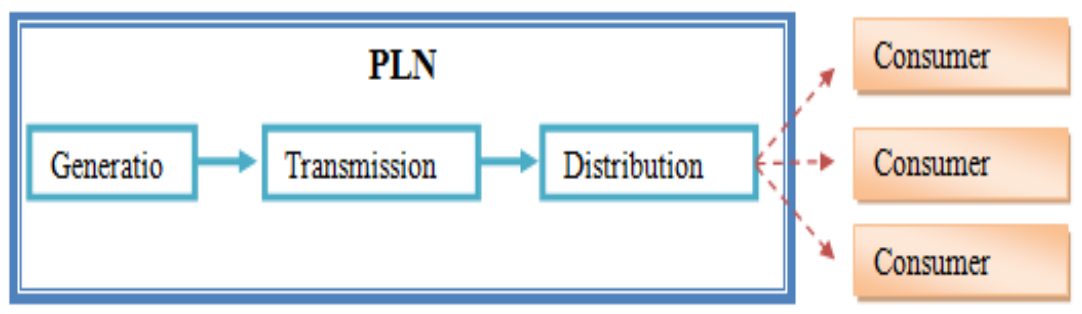

Fig. 3 Vertically Integrated Monopoly - Indonesia prior to 1985

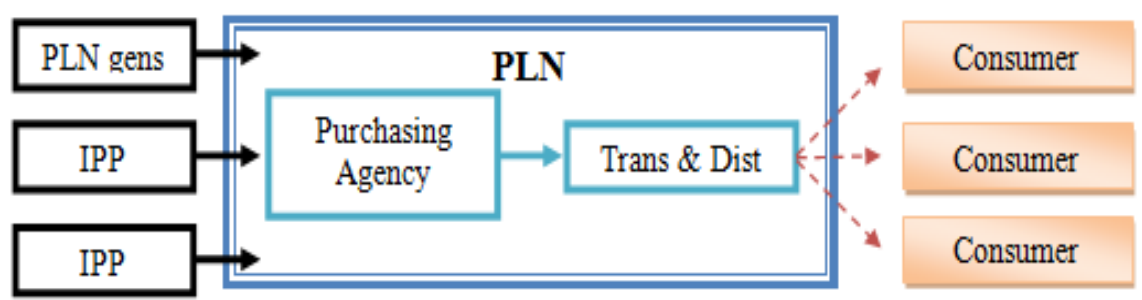

Fig. 4 Single Buyer Model / Purchasing Agency as implemented in Indonesia 
Under the least competitive design of the single buyer model, IPPs are used primarily as a source of additional capital to supplement the generation fleet of the VIPC, which retains overwhelming dominance in generating, dispatching and supplying electricity (Hassan et al. 2009). There is no centralized or transparent mechanism by which the dispatch of IPPs or the VIPC's own generators are prioritised or coordinated. Consequently, there is no guarantee for IPPs that they will receive equal treatment in dispatch alongside the VIPC generators. In turn, the IPPs generally seek highly structured PPAs that guarantee price and minimise volume risk (known as 'take-or-pay' contracts). The overall effect is that the dispatch of generators is not driven by competitive pressures as under a market arrangement, but instead is heavily influenced by PPA terms, which are in turn driven by the VIPC's planning requirements rather than a decentralised competitive process. Whilst there is some competitive pressure through investment in new generators, with the VIPC able to compare IPP bids for new power plants by their respective PPA prices, this competitive pressure is largely limited to the intitial investment stage and constrained by determining the type and location of plant by the VIPC. In addition, due to the 'take or pay' structure of PPA's the VIPC's ability to manage dispatch efficiently can be negatively affected. Thus, some of the possible economic efficiencies in construction and operation are achieved through the current structure but the benefits of competition are far from exploited under the current structure.

A more competitive form of the single buyer model is described by Lovei (2000). He describes the 'mandatory competitive pool' form of the single buyer model, where generators are not shielded from market risks by government guarantees, and wholesale prices determine dispatch and investment via market rules rather than PPAs. This arrangement is very similar to the wholesale competition model discussed below, with the primary difference being that a single purchaser commits to taking all power sold through the competitive pool, rather than passing this risk on to various distribution or retail companies. As Lovei (ibid.) notes, in that case, the single buyer model captures many of the benefits of the wholesale competition model, but faces specific difficulties associated with incentives to pursue collection of electricity tariff revenues and government interference in market processes.

Since 1985 a less competitive version of the single buyer model has emerged in Indonesia via the gradual engagement of IPPs by PLN. Whilst private investments in the form of IPP projects have helped reduce the risk of power shortages, the absence of a competitive mechanism to coordinate IPP and PLN generation means that the introduction of IPP generators only represents a fairly modest step towards the wholesale competition. In essence, the timing, capacity and fuel supply choice of new generation investments, as well as the day-to-day dispatch of plant, are determined internally by PLN rather than transparently through market prices. This would be very similar to the vertically integrated model described above but may actually be worse because PLN may be constrained in its choice of which plants to dispatch from as a result of take or pay arrangements with IPPs.

One option for Indonesia would be to improve the way in which IPPs bid to build capacity, improving the efficiency gains available from competition, without affecting the sole buyer position of PLN and consistent with the constitutional ruling in 2002. This is elaborated further in the existing lelctricity market arrangements chapter.

\section{Model 3: Wholesale competition}

Genuine competition is more likely to first emerge at the wholesale level (i.e. generation) rather than in the network element or in retailing (Song et al. 1999). The key difference between this model and the single buyer model is the existence of multiple wholesale purchasers of electricity rather than a single, central purchasing agency that commits to purchase all electricity delivered to the system. In Fig. 5, the wholesale purchasers are depicted as either distribution companies or large customers that arrange their own wholesale purchases (e.g. smelters). In this market, distribution companies can be thought of as geographic monopolies that exclusively purchase, distribute and sell electricity to small and medium sized customers in a particular region. As the transmission system connects multiple such regions, these distribution companies can choose between generation sources from within and beyond their physical region. This choice, in turn, drives genuine wholesale competition between generation companies to supply the various potential purchasers.

Transactions between generators and wholesale purchasers take place either in a decentralised wholesale market governed by bilateral contracts, through a centralised power exchange or 'pool', or a combination of both. In a 'bilateral' market, buyers and sellers individually contract with each other for quantities, price, terms and conditions. There is no single transparent market price, and prices are instead determined by the terms of individual contracts. As in traditional market, buyers and sellers interact directly to secure contracts. A bilateral market is similar to less competitive forms of the single purchasing agency model above, with the key difference that generators have a choice of counter-parties with which to agree a PPA for their output, allowing generators and off-takers to negotiate prices that reflect market conditions.

A pool trading system creates a centralised and transparent mechanism through which generators and 
Citation: Setyawan, D. (2014) Assessing The Current Indonesia's Electricity Market Arrangements and The Opportunities to Reform. Int. Journal of Renewable Energy Development, 3(1), 55-64 doi: 10.14710/ijred.3.1.55-64 $\mathrm{P}$ a g e $\mid \mathbf{6 2}$

wholesale purchasers may interact. In its strongest form, this pool is 'mandatory' in that all power must be bought and sold through the pool. Generators notionally sell all their output to the pool, rather than a specific buyer and, similarly, buyers are deemed to purchase all their output from the pool. A central Independent Market Operator (IMO) holds regular auctions where generators bid quantities and prices for the specific time period. Generators are dispatched in order of increasing price to satisfy total demand in the relevant time period, and the price of the last bid required to 'clear' the market is treated as the market price for that period: all sellers receive and all buyers pay this price in that period. Whilst all generation is notionally dispatched through the pool, mandatory pool markets nevertheless typically develop complementary financial contracts that offer participants much of the price and volume certainty they achieve in a bilateral contracting market.

Bilateral contracting and pool trading can operate in combination. In such markets, contracted quantities are dispatched preferentially irrespective of price, and generation output in excess of contracted quantities is deemed to be sold into the pool and earn the pool clearing price. Similarly, purchases by wholesale customers in excess of their contracted volumes are deemed to be purchased from the pool at the pool clearing price. Under this arrangement, pool trading essentially acts as a 'balancing' market to true-up purchases and output that is above or below contracted quantities.

Indonesia is some distance from approaching this model of wholesale competition. Firstly, wholesale competition requires the creation of multiple potential buyers to allow generators to negotiate market reflective prices. Secondly, market structure issues and pre-existing contractual arrangements are not conducive to competition between generators. To promote competition, PLN's share of total generation capacity would need to be reduced through disaggregation into separate companies that would compete with one another, and these companies would need to be separated from PLN's transmission and wholesale market dispatch functions to ensure fair treatment for competing IPPs. Further, existing PPAs with IPPs may need to be restructured so as to reflect a new competitive environment as well as being transferred from PLN to a new wholesale purchasing entity (possibly a regional electricity distributor).

Nevertheless, the emergence of genuine wholesale competition through market restructuring would offer a number of potential benefits. Firstly, forward-looking wholesale prices can be determined by market processes rather than planning processes. This dynamic motivates potential investors to optimise new entry choices across a range of feasible new generation options. Secondly, the threat of entry from new generators motivates existing generators to minimise costs. Thirdly, centralising dispatch through a pool mechanism increases the likelihood that short-run dispatch decisions minimise operating costs of the existing fleet. However, notwithstanding these benefits, significant market structure and legal barriers (not least the constitutional ruling preserving PLN's monopoly on the sale of electricity to users) means that moves to wholesale market competition will be slow and tentative in the short-term, likely reflecting adjustments within the broader confines of the single buyer model described earlier than a dramatic move towards genuine wholesale competition.

\section{Model 4: Retail competition}

Under the wholesale competition model described above, small to medium sized customers (i.e. customers not large enough to purchase directly from the wholesale market) do not have a choice of electricity supplier and are dependent on the local monopoly distributor/retailer (Sugianto 2010). Accordingly, this system lacks retail competition and requires regulation of price and access to protect the interest of small customers.

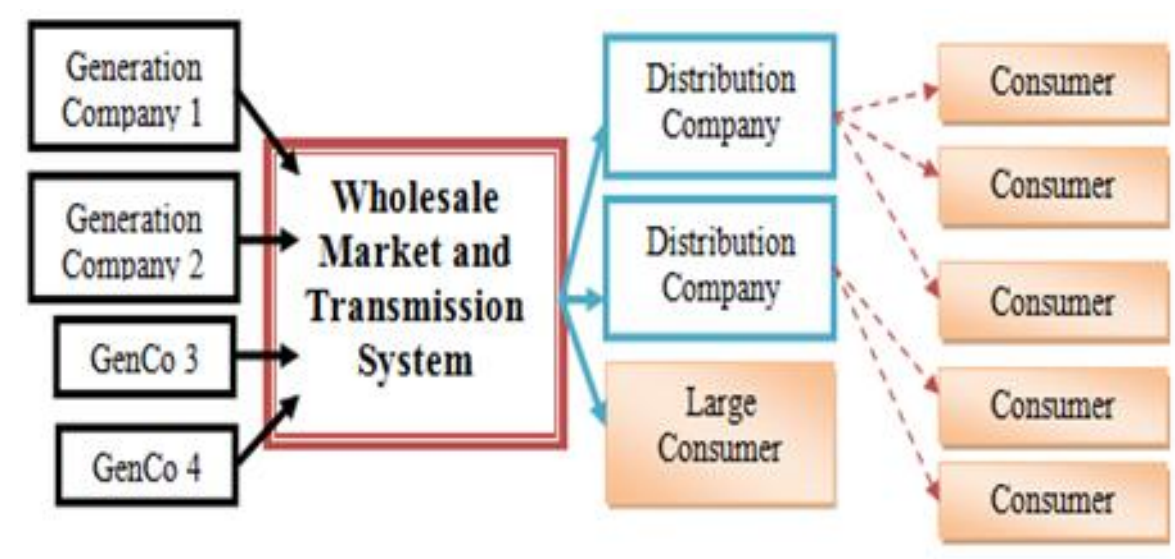

Fig. 5 Wholesale Competition 


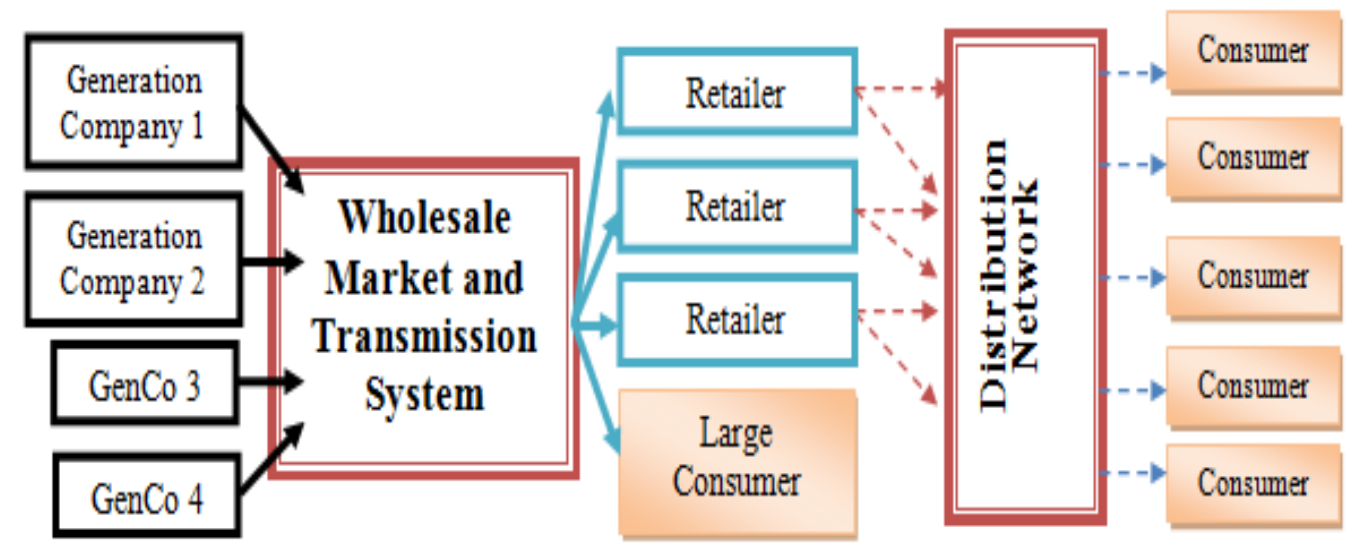

Fig. 6 Retail Competition

Accordingly, the final stage in developing a competitive electricity market structure is to facilitate competition between the final suppliers of electricity to customers, i.e. retailers (Hogan 1993). As the distribution of electricity via poles and wires has natural monopoly characteristics, this competition requires, at least, establishing rules that ensure that new entrant retailers that wish to compete with the 'incumbent' retailer-distributor has guaranteed access to use of the network on fair and competitive terms or, ideally, fully separating the retail and distribution functions to guarantee equal access rights for all retailers.

This market structure is shown in Fig. 6, but illustrates only one geographic distribution area. As under wholesale competition, multiple purchasers contract with generators or purchase electricity from the wholesale pool. However, multiple retailers also compete to supply the same customer via the monopoly distribution network, ensuring that consumers have a choice of retailers.

Under genuinely competitive retail market conditions, e.g. where the number of retailers is sufficient to provide genuine price competition, prices can no longer be regulated but can instead by determined by competition between retailers (Bohi \& Palmer 1996). The retail price no longer has to be regulated because small consumers can change retailer when they are offered a better price. From an economics perspective, this model is the most satisfactory because energy prices are set through market interactions. However, retail competition requires considerable amounts of metering, communication and data processing to function effectively. The cost of the transmission and distribution network is still charged to all their users as it is done on a regulated basis because these networks remain monopolies.

Full retail competition is notionally the end point of restructuring process from monopoly to competition. Where market design is efficient and market structures are balanced and genuinely competitive (e.g. not excessively concentrated in a few company's hands), this model can generate efficiencies in the supply of electricity that both attract capital to the supply side and benefit consumers through low prices. However, while this may be the culmination of the restructuring process described here, reforms in the Indonesian electricity sector can provide many benefits described here without going all the way to full retail competition. See the existing electricity market arrangements chapter in this publication for further details about the suggested course of action.

\section{Conclusion}

As discussed above, electricity sector reform has the potential to improve economic outcomes and reduce pressure on the budget. Without prejudicing further discussions with other areas of government and line ministries and stakeholders, some ideas about how to tackle electricity sector reform have been considered and potential directions for reform have been identified.

Our analysis of Indonesia's electricity sector indicates that the 'single buyer model' is strongly entrenched (with PLN acting as the monopoly purchaser and reseller of electricity), not least due to constitutional restrictions. However, there is significant scope to achieve more efficient outcomes by incremental reform within this broad structure. Specifically, the interaction between PLN and IPPS (particularly the form of PPAs) can be refined to encourage behaviours more akin to a competitive wholesale market, without relying on the long and uncertain process of reforming the sector to a fully competitive structure.

One option would be to create a distinct funding envelope for new tranches of generation capacity by load centre, perhaps beginning with a portion of new investment in parallel to the crash program planning model that is currently in operation. IPPs would be invited to bid for a share of the funding by offering the 
Citation: Setyawan, D. (2014) Assessing The Current Indonesia's Electricity Market Arrangements and The Opportunities to Reform. Int. Journal of Renewable Energy Development, 3(1), 55-64 doi: 10.14710/ijred.3.1.55-64

$\mathrm{P}$ a g e $\mathbf{6 4}$

largest amount of capacity at lowest cost (distinguishing peak, shoulder and base load).

This would begin a process by which new capacity is funded in a technology neutral manner and would allow fuel price risk and other operational costs to be allocated to IPPs rather than remaining with the government. This process would also better harness the professional judgement of IPPs with respect to project capacity, design, site and fuel selection, as well as responsibility for upstream (e.g. fuel supply) arrangements. If IPPs made wrong judgement calls about such factors, their profits would be negatively affected, providing strong incentives to get it right, aligning cost-minimisation incentives for the GOI and IPPs.

Under such a model, PLN would coordinate and dispatch generation from a variety of sources and integrate the generation and transmission network planning. It would be desirable to give PLN additional space to focus on transmission - a critical aspect of electricity supply and one that has enormous influence on overall costs. Of course, detailed development of such reforms would require extensive engagement within the government line ministries, PLN and industry stakeholders representing IPP viewpoints.

\section{References}

Andika, F., \& Dewanda, R. (2004) Social Analysis on Electricity Market Mechanism in Indonesia

Bohi, D. \& Palmer, K. (1996) The efficiency of Wholesale vs Retail Competition in Electricity. The Electricity Journal. Pp 12-20

Baumol, W.J. (1977). On the Proper Cost Tests for Natural Monopoly in a Multiproduct Industry. 809 American Economic Review.

Depoorter, B.W.F. (1999). Regulation of Natural Monopoly. Journal of Economics Literature
Donald, D. (1959), Monopoly in Economics and Law, Chicago, Rand McNally, 328p.

Hassan, Y., Hussin, F., \& Othman, M.F. (2009) A Study of Electricity Market Models In The Restructured Electricity Supply Industry. University Teknologi Malaysia.

Hogan, W.W. (1993) A Competitive Electricity Market Model, Harvard University

International Energy Agency (2008). Energy Policy Review of Indonesia. IEA Publications, 77-89.

Jakarta Globe (2010). PLN to seal deal with independent power producers as 2nd fast track unfolds. February 12, 2010.

Jakarta Globe (2010). Cutting Off Indonesia's Coming Energy Crisis. July 21, 2010.

Kim, S.R \& Horn, A. (1999). Regulation policies concerning natural monopolies in developing and transition economies. DESA Discussion Paper No. 8. March 1999.

Lovei, L. (2000) The Single-Buyer Model: A Dangerous Path toward Competitive Electricity Markets, World Bank Note.

Ministry of Energy and Mineral Resources (2012). Pembahasan dan Penetapan Asumsi Dasar Subsidi Listrik RUU APBN 2013. Rapat Kerja Subsidi Listrik Direktorat Jenderal Ketenagalistrikan, Kementerian Energi dan Sumber Daya Mineral, 17 September 2012.

Pintz, P., \& Korn, A. (2005) Development of a Competitive Electricity Market in Indonesia. Energy Studies Review 13(2): 56-70

Purra, M.M. (2010). The Indonesian Electricity Sector: Institutional Transition, Regulatory Capacity and Outcomes.

Sherer, F.M. (1980), Industrial Market Structure and Economic Performance. Chicago: Rand McNally.

Song, H., Liu, C.C. \& Lawarree, J. (1999) Decision making of an electricity supplier's bid in a spot market. Proceedings of the 1999 IEEE Power Engineering Society

Stănciulescu, A-M. (2004) Definition and regulation of "vertically integrated monopolies. ERRA Workshop on Legal Regulation Kiev, Ukraine

Sugianto, L.F. (2010) Simulating a Competitive Electricity Market, Proceedings of SIG GlobDev Third Annual Workshop, Saint Louis, USA.

World Bank (2005) Electricity for All: Options for Increasing Access in Indonesia

Yarrow, G. (1994), The Economics of Regulation, in: V.V. Ramanadham (ed.), Privatization and After: Monitoring and Regulation, Routledge: London and New York, pp. 35-46. 